\title{
Pattern and Determined Factors of Local Foods Consumption of SIKKATO in Kendari City Southeast Sulawesi
}

\author{
Musadar, U. Rianse, W. Widiyanti dan W. Gusmiarti. \\ Agricultural Faculty of Haluoleo University Kendari-Indonesia \\ Jl. Kelapa No 41 Andounuhu, Kendari - South East Sulawesi
}

\begin{abstract}
Local foods play an important role in maintaining food security in the area. Sinonggi, kasuami, kabuto, dan and kambose or SIKKATO for short are local foods consumed by various ethnics who settled in Kendari. The study was conducted to find out patterns and factors affecting consumption of SIKKATO. The study carried out using the method of survey involved 150 respondents who were selected based on the existing ethnics in Kendari. The data was analyzed by regression and path. The results showed that SIKKATO consumed by $94.7 \%$ of respondents, of the SIKKATO, Sinonggi was the highest $(83,3 \%)$ whereas Kambose was the lowest (18\%) consumed. SIKKATO consumption pattern varies between ethnics and other types of local foods. More than 50\% of the people consumed SIKKATO at least once in a week, even some respondents consumed SIKKATO more than 5 times in a week. Factors influencing the consumption of local food were length of stay, income, the amount of local food type consumed, levels of perception, variable of cosmopolite, and ethnics. Furthermore, factors that influence local food consumption directly was the perception, therefore to increase consumption of local food, increasing of perception is the most strategic to be conducted through a series of disseminations acting such as demonstrations, extension, and strengthening regional policy.
\end{abstract}

Keywords: pattern, determined factors, consumption, local foods SIKKATO

\section{Introduction}

Indonesia, as a tropical country which is rich in biological ressources, certainly could to develop a variety of unique and typical food. The condition is very potentially contributed to both household and national food security which was developed based on the power of local resources will shift rice as a sole food, replaced by other kind of foods so that will ultimately promote the achievement of food selfsufficiency (Haryadi P, 2010: Rauf and sustainably, 2009).

Local foods is one of the specific wealth of potential area which could be developed became sources of main food within the framework of the sustainable food security. The program of local foods development has long been proclaimed by the Government in the context of food diversity which aims to change the reliance on rice as sole food. A series of legal formal were issued preceded by the Presidential Instruction No. 14/1974, which was then enhanced with presidential Instruction No. 20/1979 about diversity of people's Food Menu and Improvement of Nutritional society and was affirmed by Presidential Regulation No. 22/2009 about the policy of the acceleration of food consumption diversity based on local food ressources (Sarma, 1985 in Hanafie 2010).

The Illustration of increasing of local food image as specific wealth can be seen in some States in the United States. Idaho has suitable environment (soil, water, sunny days, etc) to grow and to produce high-quality and famous potatoes in the word, then the potato was designated the official state vegetable. The word of "Famous potatoes" is put on the plate number car as part of registered Idaho code. Wisconsin is one of the nation's leading producers of dairy known as "America's Dairyland". The reputation is also promoted by placing the slogan, "America's Dairy land," on automobile license plates. The US State of Georgia also proudly proclaims itself as the peach state. This illustration just shows the high political commitment of the Government in the US for consistently and sustainable in developing food self-sufficiency based on potentially natural resources, human, technology, and cultural of indigenous or local assets (Haryadi 2010).

The development of local food is an alternative in supporting national food security. Abidin et al (2013) state that the development of local food was very important related to the food security in a region especially on the islands area. The development of local foods in an area can be an alternative to the development of the global food system. Boros et al (2012) stated that local foods had advantages on nutritional-psychological and privilege as well as a competitive value in food trading nationwide. The development of local foods was closely related to the life sustainability of local communities. It is further mentioned that the policy of local foods development can be the solution of food problem in rural areas through not only providing an additional benefit to society but also improving of communal characters and living environment in rural areas (Chool Choi Y and Sil Kim, 2015).

\section{Local Food of SIKKATO}

The term of local foods has various definitions in the some literatures. Husain (2004) stated that local food was a food produced in the local area for the purposes of economic and or consumption determined by the distance between production site and consumption area (Feldmann and Hamm, 2015) involving local resident (Kohsaka et al., 2016) including friends, relatives, and neighbors (Feldmann and Hamm, 2015). Feenstra. (2002) used term community foods instead of local food to describe a collaboration process of 


\section{International Journal of Science and Research (IJSR) \\ ISSN (Online): 2319-7064 \\ Index Copernicus Value (2013): 6.14 | Impact Factor (2015): 6.391}

sustainable food production including production, processing, distribution, and consumption based on local resources to improve the economic, healthy, and environment, in the specific area. Venn, et al (2006) described that local foods had four characteristics i.e. the relation of manufacture and consumer became closer and more accessible resulting in increasing of consumption; opened network of supply and distribution; adopted social principles based on trust and local culture that was specific by region; and embraced principles of good quality and environmental friendly.

Some studies use term of traditional food to describe a local food. They stated as a traditional food with the mean that not much different with the other terms. It was based on the assumption that the food is already a long time ago in the specific location and inherited from generation to generation for more than 30 years; have a positive image such as superior taste; nostalgia and ethnocentrism, typically evoke strong memories of childhood also distinctive sensory merits. Finally consumer describe traditional foods in terms of its authenticity (Guerrero et al., 2009; Almli et al., 2011; Vanhonacker et al., 2010; European Parliament and the Council of the European Union 2012; Cerjak et al., 2014; Rudawska, 2014; Molnár et al., 2011 Tregear et al., 1998). Further Balogh P et all., (2016) also use term a traditional food to describe a consumer willingness to pay for Hungarian mangalitza salami.

Yong Kwon Dae (2015) uses the term ethnic foods to describe the food comes from local wisdom by using local food ressources originated from plants as well as animals, then passed down to the next generation. P. J. Burgess (2014) also use the same term, but he emphasized its uniqueness and novelty, so that the food did not come from his own culture.

Based on the various definitions of local foods, in this study we define local foods as foods that manufactured and consumed by people in a certain area occupied by ethnics, and remains consumed although the people has leave for the region.

SIKKATO stands for local food that consists of Sinonggi, Kasuami, Kambose and Kabuto, consumed by the people of Kendari from different ethnics. Sinonggi is Tolaki ethnic's local food made from sago, consumed as one of the main foods. Kasuami is Buton ethnices local food made from cassava through several process of cooking, namely grating, pressing, and steaming.Kambose and Kabuto are local foods of Muna ethnic. Kambose is made from mature corn, cooked using lime to exfoliate epidermis, usually consumed with fish and vegetables. Kabutois made from dried-black cassava, usually consumed along with the vegetables and fish.

The study of local foods had been conducting by some researchers. Abidin et al. (2014) reviewed of food security especially in small islands in Southeast Sulawesi. He revealed the importance of local food in supporting food security. Dini. et al. (2012) studied Kasuami in Buton island as a local food, likewise, Widjanarko, et al (2012) studied the levels of fat and protein in Kasuami. However, the information and research on how local food consumption patterns at the level of household as well as the factors influences someone in consuming local food is relatively still very limited.Thefore, in this study, we focus on obtaining pattern and determined factors influencing local foods consumption.

\section{Method}

The research was conducted in Kendari city South East Sulawesi on January to March 2016 using survey method involving 150 respondents. The respondents was chosen based on clustering of ethnics i.e. Tolaki, Muna, Buton, Bugis, Makassar and other ethnics coming from South Sulawesi, Java, Bali, and other province throughout Indonesia as well as Chinese.

\section{Data Analysis}

\section{a. Perception analysis}

Perception analysis was used to analyze the level of community on SIKKATO, (Hendayana, 2011) on components as follows: (a)not a plebeian food, (b) easy to obtain, (c) nutritious food, (d) the healthy food, (e) the hygienic, (f) consumed by all profession, (g) consumed by all age of people, (h) affordable price, (i) easy serving, and (j) long period of expired time;

b. Regression and path analysis

Regression analysis was used to analyze the factors influencing consumption of local food SIKKATO (Rahman and Muhin 2007). Path analysis was used to obtain a direct and an indirect influence. Both regression analysis and path were calculated using SPSS 20.0 (IBM SPSS Statistics 20).

\section{Results}

\section{Area Characteristics}

Kendari City is located in south east of Sulawesi Island with a large land area of $267,37 \mathrm{~km}^{2}$ occupied by 335.889 people consisting of 169.371 male and 166.518 female. Agriculture is one of livelihoods contributing on GDP of Kendari City that reach 11,86\% from 13.354.996.000.000 (BPS Kendari, 2014).

Rice is only grown in 1.310 ha of irrigated rice field produced 6.969 ton of dry grain of rice annualy. Other agricultural commodities i.e. crop foods, estate crops, and horticulture crops are grown in 14.758 ha of upland area. The area planted by food crop producing corn about 999 ton every year, cassava 5.401 ton per year, and other food crops with the low production. Sago is also developed grown in Kendari with the production of 35 ton of flour every year. Climate and rainfall of $1.679 \mathrm{~mm}$ annually as wellas rainy days of 144 days every year are suitable enough to support agricultural production (BPS Kendari, 2015).

\section{Pattern of food consumption}

Pattern of food consumption of Kendari people is enough various due to availability of alternative foods such as sinonggi, kasuami, kabuto, and kambose. It is indicated by rice consumption achieved $87 \mathrm{~kg}$ annually lower than national rice consumption about $105 \mathrm{~kg}$ annually (Office of 


\section{International Journal of Science and Research (IJSR) \\ ISSN (Online): 2319-7064 \\ Index Copernicus Value (2013): 6.14 | Impact Factor (2015): 6.391}

Food Security, City Kendari, 20015; Indonesian Agency for Food Security, 2015). Level of food consumption of people in Kendari city is presented in Table 1.

Table 1: Average of Food consumption ( $\mathrm{kg} / \mathrm{capita})$ of people in Kendari, 2016

\begin{tabular}{|c|c|c|c|c|}
\hline Year & Rice & corn & cassava & Sago \\
\hline 2012 & 92.3 & 1.4 & 6.1 & 3.1 \\
\hline 2013 & 88.2 & 0.8 & 4.5 & 3.2 \\
\hline 2014 & 84.5 & 0.7 & 7 & 1.6 \\
\hline 2015 & 83.4 & 0.4 & 5.4 & 3 \\
\hline average & 87.1 & 0.825 & 5.75 & 2.725 \\
\hline
\end{tabular}

Source: Office of Food Security of Kendari, 2016.

Pattern consumption describes the household habit in providing food to the family member. It is reflected kind of local foods which is consumed by people in household (Table 2).

Table 2: Kind of local foods consumed by respondents, 2013

\begin{tabular}{|c|c|c|c|}
\hline No. & Kind of local foods & Total & Percentage (\%) \\
\hline 1 & Sinonggi & 74 & 49.3 \\
\hline 2 & Kasuami & 7 & 4.7 \\
\hline 3 & Kambose & 1 & 0.7 \\
\hline 4 & Kabuto & 4 & 2.7 \\
\hline 5 & Sinonggi and Kasuami & 15 & 10 \\
\hline 6 & Sinonggi and Kambose & 8 & 5.3 \\
\hline 7 & Sinonggi and Kabuto & 3 & 2 \\
\hline 8 & Kasuami and Kambose & 1 & 0.7 \\
\hline 9 & Kabuto and Kambose & 4 & 2.7 \\
\hline 10 & Sinonggi, Kabuto and Kasuami & 3 & 2 \\
\hline 11 & Sinonggi, Kabuto and Kambose & 1 & 0.7 \\
\hline 12 & Sinonggi, Kasuami, Kambose & 3 & 2 \\
\hline 13 & $\begin{array}{c}\text { Sinonggi, Kasuami, Kambose and } \\
\text { Kabuto }\end{array}$ & 18 & 12 \\
\hline 14 & Not eaten & 8 & 5.3 \\
\hline
\end{tabular}

Sources: Analysis of prime data, 2016

Table 2 shows that sinonggi was local food consumed by the most respondents independently or combined with other local foods such as kasuami, kambose, or kabutoin different time. For example, someone consumed sinonggi at breakfast time then consumed other local foods at lunch or supper in a week. It can be seen in the proportion of respondents who consumed all local foods of SIKKATO about $12 \%$. Furthermore, not all respondents consumed local foods, about $5,4 \%$ of them only consumed rice in their pattern of food consumption. Pattern of SIKKATO consumption measured within a week showed variation among the type of local foods as described in Table 3.

Table 3: Pattern of SIKKATO consumption in Kendari city, 2016

\begin{tabular}{|c|c|c|c|c|}
\hline \multirow{2}{*}{ Consumption pattern } & \multicolumn{4}{|c|}{ Total respondents consumed (person) } \\
\cline { 2 - 5 } & Sinonggi & Kasuami & Kambose & Kabuto \\
\hline $1-2$ times a week & 77 & 17 & 13 & 17 \\
\hline $3-5$ times a week & 17 & 4 & 3 & 0 \\
\hline$>5$ times a week & 7 & 5 & 2 & 0 \\
\hline Uncertain & 24 & 21 & 18 & 16 \\
\hline Total & 125 & 47 & 36 & 33 \\
\hline
\end{tabular}

source : Analysisof prime data, 2016
Table 3 shows that consumption patterns of SIKKATO varies between types of local food. However, it appears that more than half of respondents consumed the local food at least once a week.There are respondents who consumed Sinonggi, Kasuami and Kabuto more than 5 times in a week There is still pattern of local foods consumption of the respondents was uncertain which means that they did not consume local food within a week, but in the next week they consume once even more depending on the occasion, the willingness, and and the availability of local food supplies.

\section{People perception on SIKKATO}

A person's interest in consuming local foods is inseparable from their perception on raw food to be consumed. Perception of respondents on SIKKATO served in Table 4.

Table 4: Perception of respondents on SIKKATO in Kendari City 2016

\begin{tabular}{|c|c|c|c|c|c|}
\hline No & Parameter & agree & Hesitate & disagree & total \\
\hline 1 & Not a plebeian food & 79 & 14 & 7 & 100 \\
\hline 2 & Easy to obtain & 84 & 11 & 5 & 100 \\
\hline 3 & Nutritious food & 75 & 11 & 13 & 100 \\
\hline 4 & The healty food & 77 & 11 & 11 & 100 \\
\hline 5 & The hygienic food & 75 & 12 & 13 & 100 \\
\hline 6 & Consumed by all profession & 79 & 12 & 9 & 100 \\
\hline 7 & $\begin{array}{c}\text { Consumed by all age of } \\
\text { people }\end{array}$ & 77 & 11 & 11 & 100 \\
\hline 8 & Affordable price & 81 & 11 & 8 & 100 \\
\hline 9 & Easy serving & 82 & 11 & 7 & 100 \\
\hline 10 & Long period of expired time & 82 & 11 & 7 & 100 \\
\hline 11 & $\begin{array}{c}\text { Not delicious if doesn't } \\
\text { consumed in a week }\end{array}$ & 62 & 25 & 13 & 100 \\
\hline & Average & 78 & 13 & 9 & 100 \\
\hline
\end{tabular}

Source: Analysis of prime data, 2016

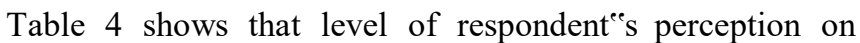
SIKKATO is high. It can be understood, because those local foods are quite well known and familiar in Kendari.In addition, promotion and anunciation of local foods associated with food security is also published massively by the Government of Kendari City. Furthermore, among 11 parameters of perception, there is only one parameter, not delicious if doesn't consumed SIKATTO in a week that has moderate level. It indicates that although its perception is high but in the implementation of daily food pattern, respondents proportion who don't yet consume SIKKATO in their daily food pattern is moderate.

Social interactions interwoven among compounded ethnics in Kendari and related to food pattern is reflected by the addition of local food in daily food pattern of people, although the frequency of consuming local food by indigenous ethnics is strong enough. This cannot be denied because the food patterns have formed long ago and inherited in the family. The relationship between ethnicity and patterns of food is presented in Table 5. 


\section{International Journal of Science and Research (IJSR) \\ ISSN (Online): 2319-7064}

Index Copernicus Value (2013): 6.14 | Impact Factor (2015): 6.391

Table 5: The relation between ethnics and consumption of SIKKATO in Kendari City, 2016

\begin{tabular}{|c|c|c|c|c|c|c|c|c|c|}
\hline \multirow{2}{*}{ NO } & \multirow{2}{*}{ ETNICS } & \multicolumn{4}{|c|}{ Frequency of consumption every week } & \multicolumn{4}{|c|}{ Total average to be consumed every week } \\
\hline & & SINONGGI & KASUAMI & KAMBOSE & KABUTO & SAGU & KASUAMI & KAMBOSE & KABUTO \\
\hline 1 & Tolaki & 3 & $<1(0.19)$ & $<1(0.14)$ & $<(0.11)$ & 1.8 & 0.18 & 0.1 & 0.02 \\
\hline 2 & Muna & $<1(0.6)$ & $<1(0.1)$ & $<1(0.7)$ & $>1(1, .1)$ & 0.62 & 0.33 & 0.57 & 1.04 \\
\hline 3 & Buton & $<1(0.8)$ & $>1(1.6)$ & $<1(0.2)$ & $<1(0.1)$ & 0.67 & 1.58 & 0.16 & 0.03 \\
\hline 4 & $\begin{array}{l}\text { Bugis/Makasar } \\
\text { /Toraja/Mandar }\end{array}$ & $>1(1.4)$ & $<1(0.1)$ & $<1(0.1)$ & $<1(0.2)$ & 0.8 & 0.02 & 0.02 & 0.02 \\
\hline 5 & Jawa/Sumatera/Bali/lainnya & $>1(1.1)$ & $<1(0.1)$ & $<(0.1)$ & $<(0.1)$ & 0.83 & 0.02 & - & - \\
\hline 6 & Tionghoa & $<1(0.7)$ & - & - & - & 0.3 & - & - & - \\
\hline
\end{tabular}

Table 5 describes that in overall, SIKKATO was consumed by all ethnics in Kendari. However, there is a tendency that each ethnic consume "more" local foods coming from their ethnic group. As an example, ethnic of Tolaki consumes Sinonggi3 times a week spending sago about 1.8 $\mathrm{kg} /$ family/weekend, higher than that of other ethnics. Similarly, Muna ethnic consumed kambose and Kabuto more numerous than that of other ethnic as well as Buton ethnic consumed Kasuami greater and more frequency than that of other etnics.

Another interesting thing reveal in Table 5, that the frequency of consuming sinonggi by ethnics from South Sulawesi and other ethnic (Java, Bali, Sumatra, NTT, etc.) is higher compared to the Muna and Buton ethnic. It reflects that ethnic "outside Southeas Sulawesi province" tend to select Sinonggi as their food variation, while the Muna and Buton ethnic that is ethnic "within Southeast Sulawesi province" choose to consume their own local food. Similarly, the Chinese ethnic also "only" included Sinonggi in the pattern of their daily food though the frequency is still relatively low.

\section{Factors Affecting SIKKATO consumption}

Factors affecting the rate of consumption of SIKKATO analyzed by multiple linear regression model shows that the regression equation is quite good with value $\mathrm{R} 2$ of 0.388 and value $F$ of 8,808 . It is significant on a confident level of 99 percent.

Table 6: Parameter value of multiple linier regression analysis Berganda, factors affecting level of local food consumption of SIKKATO in Kendari, 2016

\begin{tabular}{|c|c|c|c|c|}
\hline No. & $\begin{array}{c}\text { Degree of freedom } \\
(\mathrm{X})\end{array}$ & \begin{tabular}{|c|} 
Regression \\
coefficient (bi)
\end{tabular} & t-value & Significance \\
\hline 1 & (Constant) & -3.796 & -2.807 & $* *$ \\
\hline 2 & Age & -0.009 & -0.419 & ts \\
\hline 3 & Education & -0.03 & -0.751 & ts \\
\hline 4 & $\begin{array}{l}\text { Number of family } \\
\text { member }\end{array}$ & 0.126 & 1.221 & ts \\
\hline 5 & Length of stay & 0.038 & 2.406 & $*$ \\
\hline 6 & Income & $-1.81 \mathrm{E}-07$ & -1.759 & $*$ \\
\hline 7 & $\begin{array}{l}\text { The amount of local } \\
\text { food type consumed }\end{array}$ & 0.559 & 3.358 & $* *$ \\
\hline 8 & Cosmopolite & 1.689 & 1.998 & $*$ \\
\hline 9 & Perception & 4.294 & 3.994 & $* * * *$ \\
\hline 10 & Gender & 0.233 & 0.691 & ts \\
\hline \multirow[t]{3}{*}{11} & Ethnics & 0.849 & 2.344 & $*$ \\
\hline & $\mathrm{R} 2$ & 0,388 & & \\
\hline & F hit & 8.808 & & $* * * *$ \\
\hline
\end{tabular}

$\mathrm{ns}=$ non significantat $=0,05$

Table 6 shows that length of stay, the amount of local food type consumed, level of cosmopolite, perception, and ethnic have positive influence, and the variable income of respondents has negative effect on level of local food consumption rate in Kendari.

Length of stay will affect someone in consuming, because the longer they stayed in one place it will had the longer social interactions with the surrounding community so that it would ultimately influence in pattern of local food consumption. It is in line with the research conducted by Kohsaka et al., 2016 who studied local food in Japan. He stated that people who live longer has the experience and ability to introduce local food diversity to other residents and spreading through social network.

The effect of the amount of types of local food consumed will increase the level of SIKKATO consumption. This is because the more number of local food type to be consumed, there will be more options every day and ultimately enhance local food consumption. More about the level of cosmopolite having positive influence, it can be explained that a person who interact with the outside world will cause any change in behavior, including influence in consuming local food.

Positive perception (Table 1) enables someone to receive and to consume different type of local foods, therefore the perception has significant effect on level of local food consumption. There is positive relation between perception and level of consumption. Pieniek et all (2009) stated that there was positive relation between motivation in selecting food and attitude and consumption of local foods. It explicitly reflects the existence of a close link between the perception and the consumption of local food. This is because the motivation of selection is essentially influenced by the perception of a person.

Income has negative effect on local food consumption, it was indicated that the higher person "s income, then the lower local food consumption. This is possibly because with the increasing of person's income, then they have the options to select different types of foods to be consumed. It is also in line with the theory of consumption stating that income is one of the decisive factor in consumption.

Ethnic is very influential on local foods consumption level, in general, ethnic who come from Southeast Sulawesi consume local food SIKKATO greater than that of ethnics come from outside Southeast Sulawesi. To know the variables that influence directly and indirectly, path analysis 


\section{International Journal of Science and Research (IJSR) \\ ISSN (Online): 2319-7064 \\ Index Copernicus Value (2013): 6.14 | Impact Factor (2015): 6.391}

was used by making regression on affecting variables (Table direct and indirect linkages (Figure 1).

7), then put it in accordance with the order of magnitude of

Table 7: Regression Analysis of affecting variables on level of consumption of SIKKATO

\begin{tabular}{|c|c|c|c|c|c|c|}
\hline No. & Variables & Regression coefficient & Standard error & Beta (standard z) & t-value & significance \\
\hline 1 & (Constant) & -3.602 & -3.885 & & -3.885 & 0 \\
\hline 2 & Length of stay & 0.039 & 2.914 & 0.211 & 2.914 & 0.004 \\
\hline 3 & Income & $-1.98 \mathrm{E}-07$ & -1.957 & -0.144 & -1.957 & 0.052 \\
\hline 4 & the amount of local foods type & 0.633 & 3.944 & 0.276 & 3.944 & 0 \\
\hline 5 & Level of cosmopolite & 1.329 & 1.776 & 0.131 & 1.776 & 0.078 \\
\hline 6 & Perseption & 4.731 & 4.451 & 0.327 & 4.451 & 0 \\
\hline & R2 & F-value & \multicolumn{5}{|c|}{0,329} \\
\hline
\end{tabular}

$\mathrm{F}(0,05)=2,363$

$\mathrm{F}(0,01)=3,242$

$\mathrm{t}-\operatorname{tab}(0,05)=1,980$

$\mathrm{t}-\operatorname{tab}(0,01)=2,617$

Table 8: The result of regression analysis of affecting variables on perception

\begin{tabular}{|c|c|c|c|c|c|c|}
\hline No. & Variable & Regression coefficient & Std. Error & Beta (standard z) & t-value & $\rho$-value \\
\hline 1 & (Constant) & 0.636 & 0.05 & & 12.83 & 0 \\
\hline 2 & Length of stay & 0.004 & 0.001 & 0.313 & 4.041 & 0 \\
\hline 3 & Income & $-5.71 \mathrm{E}-09$ & 0 & -0.06 & -0.722 & 0.471 \\
\hline 4 & The amount of local food type consumed & 0.034 & 0.012 & 0.213 & 2.764 & 0.006 \\
\hline 5 & cosmopolite & 0.096 & 0.058 & 0.137 & 1.66 & 0.099 \\
\hline & R2 & \multicolumn{5}{|c|}{0.161} \\
\hline
\end{tabular}

$\mathrm{F}(0,05)=2,6832$

$\mathrm{F}(0,01)=3,9464$

$\mathrm{t}-\operatorname{tab}(0,05)=1,960$

$\mathrm{t}-\operatorname{tab}(0,01)=2,576$

Table 9: Correlation analysis on affecting variables on level of local foods consumption of SIKKATO

\begin{tabular}{|c|c|c|c|c|c|c|}
\hline & $\mathrm{X} 4$ & $\mathrm{X} 5$ & $\mathrm{X} 6$ & $\mathrm{X} 7$ & $\mathrm{X} 8$ & $\mathrm{Y}$ \\
\hline $\mathrm{X} 4$ & 1 & 0,115 & 0,107 & $-0,041$ & $0,323^{* *}$ & $0,324^{* *}$ \\
\hline $\mathrm{X} 5$ & & 1 & $-0,080$ & $0,374^{* *}$ & 0,010 & $-0,090$ \\
\hline $\mathrm{X} 6$ & & & 1 & $-0,115$ & $0,236^{* *}$ & $0,372^{* *}$ \\
\hline $\mathrm{X} 7$ & & & & 1 & 0,078 & 0,062 \\
\hline $\mathrm{X} 8$ & & & & & 1 & $0,469^{* *}$ \\
\hline $\mathrm{Y}$ & & & & & & 1 \\
\hline
\end{tabular}

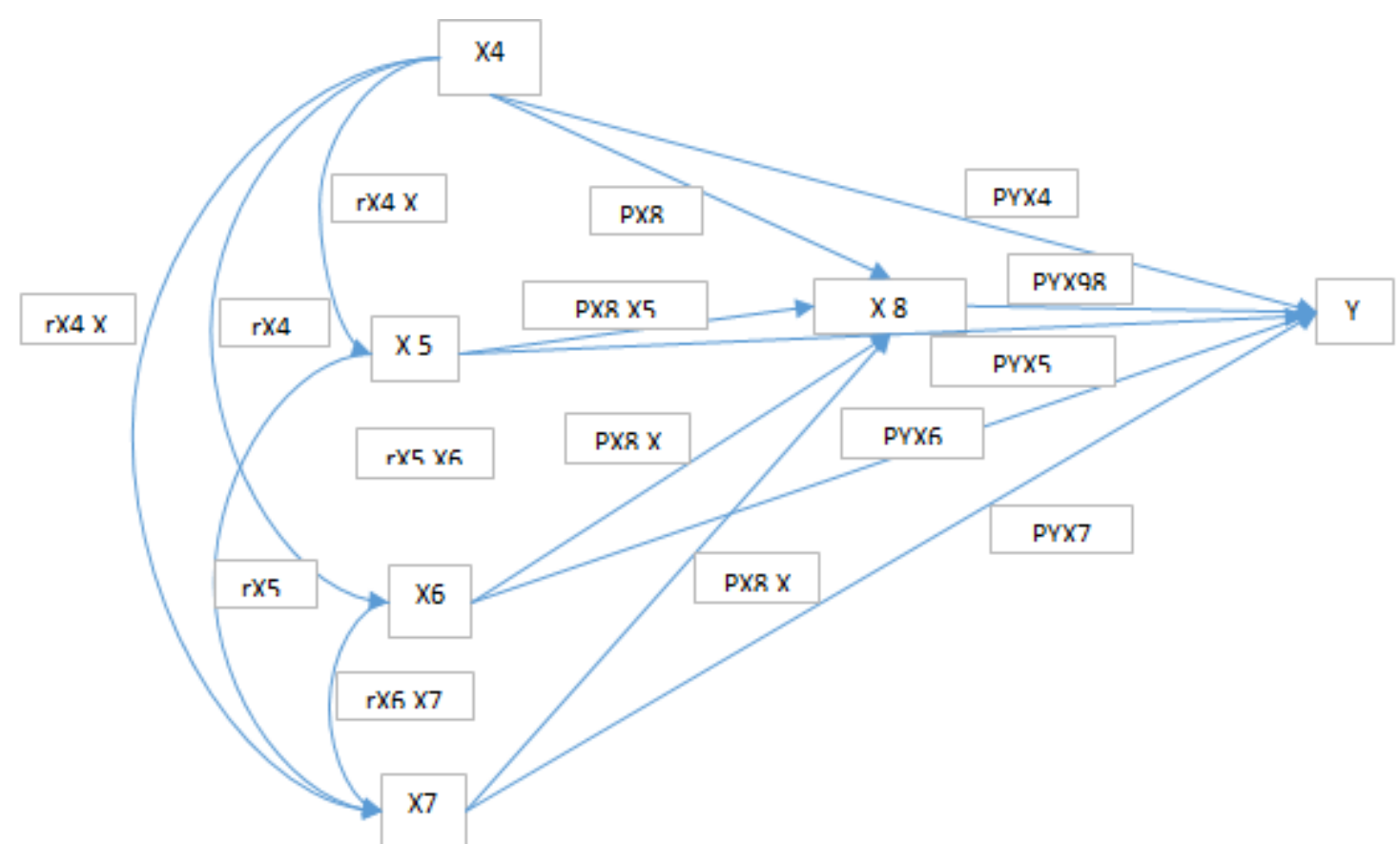

Picture 1: Direct and indirect relation factors affecting local foods consumption of SIKKATO in Kendari

Volume 5 Issue 8, August 2016 www.ijsr.net

Licensed Under Creative Commons Attribution CC BY 


\section{International Journal of Science and Research (IJSR) \\ ISSN (Online): 2319-7064}

Index Copernicus Value (2013): 6.14 | Impact Factor (2015): 6.391

Path analysis results showed that to increase consumption of SIKKATO, the factor of perception is is the main determinant factors. Other factors i.e. length of stay, income, the amount of local food type consumed, and the level of cosmopolite basically support an increase in the perception of increased local food consumption. Related to the result, the effort to increase perception need to continue to do through extension or other dissemination channel. Azhari (2013) studied concerning the role of the extension or socialisation in food diversification showed that the important aspects to be strengthened and maximized are the extension, promotion through printed and electronic media, and other social media.

\section{Conclusion and Policy Implication}

\section{Conclusion}

Local food of SIKKATO can be food alternative for people in Kendari to support food security and territory. Local foods of SIKKATO consumed by $94.7 \%$ of people in Kendari coming from variety of ethnics although with different levels of consumption. Pattern of local foods consumption was vary, but more than $50 \%$ of the community consumed SIKKATO at least once in a week, some even taking it more than 5 times a week. This pattern is interspersed with rice as the staple food. Factors affecting the consumption of SIKKATO were length of stay, income, the amount of local food type consumed, levels of perception, variable of cosmopolite, and ethnics. Factors directly affect local food consumption was the perception.

\section{Policy Implications}

To develop local food SIKKATO toward, it needs to increase the perception of the community with a wide range of activities such as dissemination of the superiority or the advantages of local foods both directly and through the online media.In addition, it should be supported by government policy such as by the strengthening of regional regulations of SIKKATO.

\section{References}

[1] Abidin Z., S. Bananiek, S. dan Muh. Taufiq R. 2013. Profil kemandirian pangan pulau-pulau kecil di Sulawesi Tenggara. Dalam Buku Membangun Kemandirian Pangan Pulau-Pulau Kecil dan Wilayah Perbatasan. Editor. Efendi Pasandaran, E. E. Ananto, Kedi S., Nono S.S., Bambang I., Haryono S dan Agung H. IAARD Press. Jakarta.

[2] Almli, V.L., Verbeke, W., Vanhonacker, F., Næs, T., Hersleth, M., 2011. General image and attribute perceptions of traditional food in six European countries. Food Qual. Prefer

[3] Ariani M. 2010. Analisis konsumsi pangan tingkat masyarakat mendukung pencapaian diversifikasi pangan. Jurnal gizi Indonesia Vol 33 No. 1. IPB Bogor. Hal 20 - 28

[4] Azhari R., P. Muljono dan P. Tjitropranoto. 2013. Peran penyuluh dalam peningkatan diversifikasi pangan rumahtangga. Jurnal agro ekonomi vol 31 No 2. Pusat Penelitian Sosial Ekonomi dan Kebijakan Pertanian. Bogor. Hal $181-198$
[5] Balogh P, Dániel Békési, Matthew Gorton, József Popp , Péter Lengyel. 2016. Consumer willingness to pay for traditional food products. Food Policy 61. 176-184

[6] Boros P, Zsuzsanna Bogone Toth and Orsolya Feher. (2013) The economic and marketing importance of local food products in the business policy of a Hungarian food retail chain. Procedia - Social and Behavioral Sciences 81. $589-594$

[7] Burgess P. J. 2014. Modification of a traditional Korean food product (Gochujang) to enhance its consumer acceptability as an ethnic food. J Ethn Foods 1 . 13-18

[8] Cerjak, M., Haas, R., Brunner, F., Tomic' , M., 2014. What motivates consumers to buy traditional food products? Evidence from Croatia and Austria using word association and laddering interviews. Brit. Food J. 116, 1726-1747.

[9] Dian Dini, Muhammad Taufiq Ratule, Bungati dan Wa Ode Lutiana. 2012. Kasoami Sebagai Pangan Lokal Masyarakat Buton dalam Mendukung Kemandirian Pangan Nasional. Prosiding Seminar Nasional" Meningkatkan daya saing dan nilai tambah produk pertanian berbasis sumberdaya lokal. Kerjasama Universitas Padjajaran Bandung, Badan Riset Daerah Provinsi Jawa Barat dengan BPTP Jawa Barat. Bandung

[10]Feenstra G. Creating space for sustainable food systems: lessons from the field. Agric Human Values 2002;19:99e106

[11]Feldmann C and Hamm U. Consumers' perceptions and preferences for local food: a review. Food Qual Prefer 2015;40:152-64.

[12] Guerrero, L., Guàrdia, M.D., Xicola, J., Verbeke, W., Vanhonacker, F., Zakowska-Biemans, S., Sajdakowska, M., Sulmont-Rossé, C., Issanchou, S., Contel, M., Scalvedi, M.L., Granli, B.S., Hersleth, M., 2009. Consumer-driven definition of traditional food products and innovation in traditional foods. A qualitative crosscultural study. Appetite 52, 345-354.

[13]Hardono, G.S. 2014. Strategi pengembangan diversifikasi pangan local. Analisis kebijakan pertanian Vol 12 No 1. Pusat Sosial Ekonomi dan Analisis Kebijakan Pertanian. Bogor. Hal $1-17$

[14]Hidayah N. 2011. Kesiapan psikologis masyarakat pedesaan dan perkotaan menghadapi diversifikasi pangan pokok. Jurnal Humanitas Vol 8 No 1.

[15] Kohsaka R, Hikaru M., and Uchiyama Y. 2016. Capturing the relationships between local foods and residents: A case in the Noto region, Japan. Journal of Ethnic Foods. available in Science Direct. journal homepage: http://journalofethnicfoods.net

[16] Kwon Dae Young. 2015. What is ethnic food? Journal of Ethnic Foods 2. 1

[17] Molnár, A., Gellynck, X., Vanhonacker, F., Gagalyuk, T., Verbeke, W., 2011. Do chain goals match consumer perceptions? The case of the traditional food sector in selected European Union countries. Agribusiness 27, 221-243.

[18] Rauf A. W dan Martina. S. T. 2011. pemanfaatan komoditas pangan lokal sebagai sumber pangan alternatif di papua. Jurnal Litbang pertanian Vol 28 No 2. Badan Penelitian dan pengembagan Pertanian. Jakarta 


\section{International Journal of Science and Research (IJSR) \\ ISSN (Online): 2319-7064}

Index Copernicus Value (2013): 6.14 | Impact Factor (2015): 6.391

[19] Rudawska, E.D., 2014. Customer loyalty towards traditional products - Polish market experience. Brit. Food J. 116, 1710-1725

[20] Tregear, A., Kuznesof, S., Moxey, A., 1998. Policy initiatives for regional foods: some insights from consumer research. Food Policy 23, 383-394.

[21] Vanhonacker, F., Lengard, V., Hersleth, M., Verbeke, W., 2010. Profiling European traditional food consumers. Brit. Food J. 112, 871-886.

[22] Venn, L. et al. (2006). Researching European „Alternative ${ }^{\text {ee }}$ Food Networks: Some Methodological Considerations, Area 38(3), 248-58.

[23]Pieniak, Z., Verbeke, W., Vanhonacker, F., Guerrero, L., Hersleth, M., 2009. Association between traditional food consumption and motives for food choice in six European countries. Appetite 53, 101-108. 